\title{
Empirical Analysis on the Positive Feedback Effect of Ideological and Political Work in Private Universities Based on Bifurcation Mathematical Model
}

\author{
Yun Sun \\ Jinqian College, Kunming University of Science and Technology, Kunming, China \\ s_un_yun1@126.com
}

\begin{abstract}
Keywords: Dynamic adjustment; Bifurcation mathematical model; Positive feedback; Empirical analysis; Linear fitting value; Regression relationship
\end{abstract}

\begin{abstract}
With the expansion of higher education, private university expands constantly like bamboo shoots after a spring rain. Private universities' ideological and political education have become the important position of national Ideological and political education. Only if we better promote the ideological and political quality's improvement, can socialist countries' advantages give better play. According to cognitive analysis of the private universities' ideological and political education, the paper constructs the dynamic adjustment and bifurcation mathematical model of ideological and political education in the process of practice teaching. The paper makes correlation analysis of individual effect, finally it concludes that paying attention to private universities' ideological and political education will have positive feedback teaching effect. The paper strives to provide a scientific basis and route for the private universities' ideological and political research and practice teaching.
\end{abstract}

\section{Introduction}

The private universities' ideological and political education are the research hotspot in the field. How to enhance the ideological and political work's efficiency, the features of private university are ideological and political education worker' particular concern[1]. At present, there are some researches on the private universities' ideological and political work.For example, Lizhongqing and Lichunxia's research on private universities' ideological and political work, it mainly emphasizes the importance on the improvement of current ideological and political education. The paper analyzes the current situation and characteristic of private universities' ideological and political work. Three aspects were discussed, such as the working train's change, work attitude's change and work efficiency's improvements. Feihexiang and Liying's discussion on private universities' ideological and political work's mechanism innovation. The paper mainly expounds private universities' ideological and political work's key point from five aspects. The paper analyzes private universities' ideological and political work's investment main body, and it analyzes investment channel's special nature. The paper puts forward that the private universities' ideological and political work's mechanism is the total. Improving private universities' ideological and political work's mechanism have a special significance for university students' ideological and political education. Songbin, Fengshujuan's several thinkings on private universities' ideological and political work,The paper analyzes that private universities should establish and perfect ideological education's mechanism under the network's environment[2]. It is coupled with the particularity of private universities from the students' perspective. Chenjing, Liuailing, Lumingyuan's brief analysis on the characteristics of ideological and political work in universities, the private universities' ideological and political work characteristics are analyzed. According to the particularity of the teaching system, the paper improves teaching environment and other aspects

\section{The developing cognition of private universities' ideological and political education}

Since the establishment of the first private university in 1982, private universities are developing at very rapid speed. Especially after entering twenty-first Century, Chinese economic developes rapidly, and the cultural atmosphere's advantages are obvious[3]. At the same time, the government 
has a positive encouragement policy for private education, which makes the development of private universities change rapidly. Private universities should seize the opportunities and develop the ideological and political education. It improves the mechanism of private universities' education, and it gives full play to ideological and political work. Generally speaking, problems and challenges in private universities' ideological and political education are shown as below.

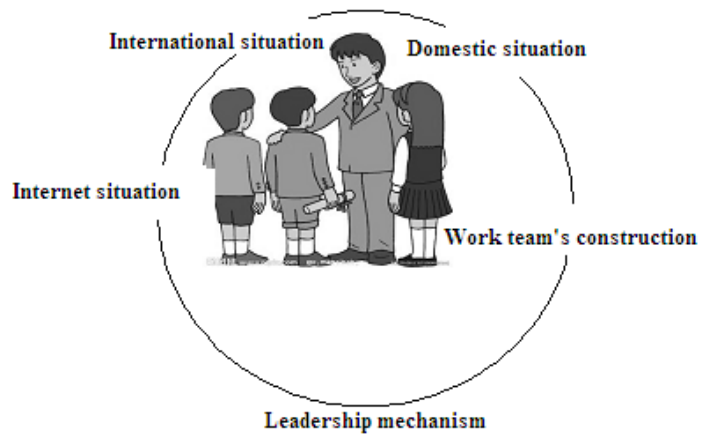

Figure 1. Problems to be solved and challenges of private universities' ideological and political education

As the Figure shown, problems to be solved and challenges of private universities' ideological and political education mainly includes the international situation, the domestic situation, the internet situation, work team building and leadership mechanism. The international situation refers to that international situation's profound changes brings some impact wave to ideological and political work. Domestic form's continued development has new requirements for the private university, and it brings new task at the same time. Specific details are shown as the following Table.

TABLE I. THE INTERNATIONAL AND DOMESTIC SITUATION'S INFLUENCE ON PRIVATE UNIVERSITIES' IDEOLOGICAL AND POLITICAL EDUCATION

\begin{tabular}{|l|l|}
\hline \multicolumn{1}{|c|}{$\begin{array}{c}\text { Changes in } \\
\text { the form }\end{array}$} & \multicolumn{1}{c|}{ Main reason } \\
\hline \multirow{4}{*}{$\begin{array}{l}\text { International } \\
\text { situation }\end{array}$} & $\begin{array}{l}\text { The formation of the economic crisis makes the } \\
\text { employment situation which is not good } \\
\text { enough one disaster after another; }\end{array}$ \\
\cline { 2 - 3 } & $\begin{array}{l}\text { Influenced by traditional concept of marketing, } \\
\text { people have certain bias for private institutions; }\end{array}$ \\
\cline { 2 - 3 } Domestic & $\begin{array}{l}\text { Private universities' ideological and political } \\
\text { education has to accept more pressure. }\end{array}$ \\
\hline \multirow{5}{*}{ situation } & $\begin{array}{l}\text { The rapid development of private universities } \\
\text { makes the whole teaching unbalanced } \\
\text { distribution; }\end{array}$ \\
\cline { 2 - 3 } & Teachers have certain negative emotions; \\
\cline { 2 - 3 } & $\begin{array}{l}\text { The family is also a question that private } \\
\text { universities' ideological and political work } \\
\text { needs to pay attention to. }\end{array}$ \\
\hline
\end{tabular}

Young students are the internet 's loyal fans. The network has a positive side and negative side for the private universities' ideological and political education. Private universities' ideological and political work group's quality is in uneven level, and it also is a reason that affects the private universities' ideological and political work. Specific details are shown as the following Figure.

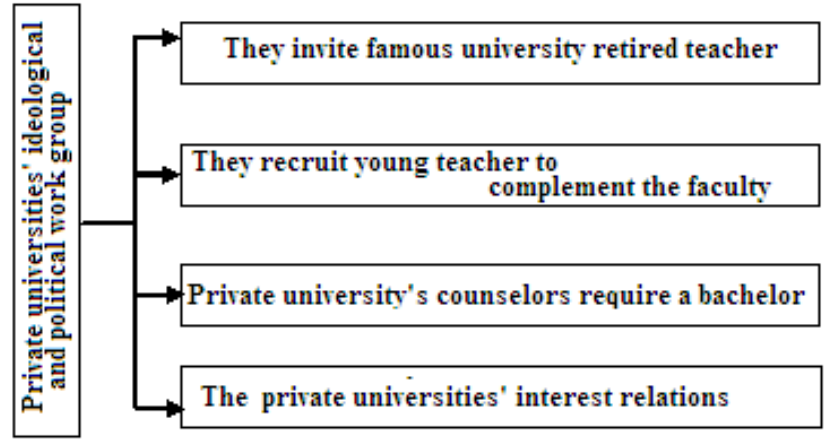

Figure 2. Private universities' ideological and political work group's quality level

As Figure. 2 shown, private universities' ideological and political work group's quality is in uneven level. At the same time, the leader mechanism is the headmaster's responsibility system under the leadership of the school board, and school running is under the leadership of president[4]. The president is the school 's supreme leader secretary, and secretary of the college's Party committee is a middle-level cadres. The board of directors consider more about capital investment teaching's profit, and it has certain obstacle to ideological and political education's investment. Private universities obtain high tuition fees with their admissions, and ideological and political 
education's investment is a long-term work. Some private universities' enthusiasm to the ideological and political education work is not high, and the plan is not clear in the actual work. The common point is that executive power is not enough.

3 Dynamic adjustment and bifurcation mathematical model of constructing ideological and political education

The rapid development of private universities is a good thing for the whole higher education, but it is full of challenges for higher education ideological and political education's work. Facing the new situation, new environment, teaching system, personalized students and teaching subject's particularity, private universities need go deep into reality. It continues to play the main role and makes a positive contribution for the healthy development of higher education.

Private universities should give full play to the subjective initiative in the new environment. In the implementation of the ideological and political education, each individual student is given a influenced person dependent variable $y$ and $n$ group preliminary observations $x_{1}, x_{2}, \ldots, x_{\mathrm{p}}$. It constructs the $F$ test and regression coefficient of the ${ }^{t}$ test of the political education differences students dynamic adjustment and bifurcation mathematical model. Ideological and political work's efficiency is to observe the independent variable $x_{1}, x_{2}, \ldots, x_{\mathrm{p}}$ from the whole students to the individual student, and it observes that if random dependent variable ${ }^{y}$ have obvious influence to ideological and political education. Its model is as follows[5]:

$$
\left\{\begin{array}{l}
H_{0}: \beta_{1}=\beta_{2}=\cdots=\beta_{p}=0 \\
H_{1}: \beta_{i} \neq 0,1 \leq i \leq p
\end{array}\right.
$$

If the $H_{0}$ is accepted by the whole group, and individual students accept it. Those show that the $y$ has no negative influence to $x_{1}, x_{2}, \ldots, x_{\mathrm{p}}$. In order to better explain the differences in students dynamic adjustment, it decomposes the observed values' deviation square. The ideological and political work should pay attention to the western negative thoughts. The western negative thoughts have a profound effect on private college students. Observed values $y_{1}, y_{2}, \ldots, y_{n}$ have differences, such as postmodernism, it adheres to the philosophy's critical thought, and it pays more attention to age. There is a linear relation between $y$ and $x_{1}, x_{2}, \ldots, x_{\mathrm{p}}$. To a certain extent, ideological and moral cultivation which is not conducive to the young students is towards the road of positive development. Young students should remove bad platinum. Different $x_{1}, x_{2}, \ldots, x_{\mathrm{p}}$ cause different $y_{i}(i=1,2, \ldots, n)$. New liberalism is in the guise of lax under the banner of freedom .It slackens private college students' marxism firm belief. In the face of society more material and worship individualism, except the factors of $y$ and $x_{1}, x_{2}, \ldots, x_{\mathrm{p}}$ linear relationship, such as non-linear effects and random factors of $x_{1}, x_{2}, \ldots, x_{\mathrm{p}}$ to $y$, private universities must use dialectical materialism to firm private college students' ideological beliefs, and guide the students' mathematical correct positive life goals and ideals.

Note ${ }^{\bar{y}=\frac{1}{n} \sum_{i=1}^{n} y_{i}}$, then the data's total sum of deviation square is as follows[6]:

$$
S S T=\sum_{i=1}^{n}\left(y_{i}-\bar{y}\right)^{2}
$$

Formula (2) reflects the data's fluctuation. The private university's ideological and political education give full play to the student's subjective initiative, and they stimulate students' interest in learning ideological and political education online. Residual sum of squares is as follows[7].

$$
S S T=\sum_{i=1}^{n}\left(y_{i}-\hat{y}_{i}\right)^{2}
$$

It reflects the factors removal of the linear relationship between $y$ and ${ }^{x_{1}}, x_{2}, \ldots x_{\mathrm{p}}$.Many students' family environment is superior, and the students enter private universities because of poor academic performance. For the ideological and political educators, they can go deep among the students. ${ }^{y_{1}}, y_{2}, \ldots, y_{n}$ 's fluctuations, it need to pay attention to the gap between the rich students' 
families and the poor students' families. In the face of the high tuition, many students achieve their dream of going to the University through student loans or school easy access. If $S S E=0$, then each observation can be made precise fitting linear relationship. If the SSE is greater, education differences between students dynamic adjustment and bifurcation mathematical fitting value deviation is greater. The regression square sum is as follows[8].

$$
S S R=\sum_{i=1}^{n}\left(\hat{y}_{i}-\bar{y}\right)^{2}
$$

$\frac{1}{n} \sum_{i=1}^{n} \hat{y}_{i}=\bar{y}$

can be concluded from Formula (4), so SSR reflects the linear fitting value and their average value. Such as network's two-sided, the student can receive latest thinking through the network. The negative thing is that network is full of corrupt information for students. Because of illegal use of internet, it lets a few bad information spread into college students' vision. That bring a lot of challenges for the ideological and political work. $y_{1}, y_{2}, \ldots, y_{n}$ are induced by the variable change of $^{x_{1}}, x_{2}, \ldots, x_{\mathrm{p}}$. If $S S R=0$, then every fitting values are equal. $\hat{y}_{i}$ isn't induced by $x_{1}, x_{2}, \ldots$, $x_{\mathrm{p}}$, and this means $\beta_{1}=\beta_{2}=\cdots=\beta_{p}=0$.It can be proved by using algebraic operation and normal equation (5)[9]:

$$
\sum_{i=1}^{n}\left(y_{i}-\bar{y}\right)^{2}=\sum_{i=1}^{n}\left(\hat{y}_{i}-\bar{y}\right)^{2}+\sum_{i=1}^{n}\left(y_{i}-\hat{y}_{i}\right)^{2}
$$

That is[10]:

$$
S S T=S S R+S S E
$$

The SSR is more larger, which illustrates that relationship between the described $y_{1}, y_{2}, \ldots y_{n} . y$ and $x_{1}, x_{2}, \ldots, x_{\mathrm{p}}$ 's linear is more significant.It is better to fit difference of education students dynamic adjustment and bifurcation mathematical. It understands all aspects of students' status in the ideological and political education, and it carries out the ideological and political education's work. It makes each student in the university to clear his political beliefs and establish a strong sense of social responsibility. It helps university students to construct the strong teamwork ability. In the current primary stage of socialism, it showes that a college student should work hard and have persevering spirit. Then it develops a strong psychological quality, and ultimately it achieves allround development.

\section{Empirical analysis of positive feedback teaching effect}

Private universities are the results of Chinese higher education's expansion. With the development of education, the private universities have gradually become an important part of higher education in china. Because of development of current private university, ideological and political education work platform are gradually mature, but the scientificalness and innovativeness of ideological and political work are obviously embodied. You can test the teaching effect by using $F$ statistic. $F$ statistic is as follows[11,12]:

$$
F=\frac{M S R}{M S E}=\frac{S S R / p}{S S E /(n-p-1)}
$$

When $H_{0}$ is true, $F \sim F(p, n-p-1)$ is referred that private universities' ideological and political work is not strong. Ideological and political education work's emphasis is not enough, and the ideological and political work's significance and supervision do not play a significant role. The main reason is that the private universities social approval is not high, and the students' own cognitive degree to ideological and political education is not high. Significance level $\alpha$ is given.Then it checks $F$ distribution table and concludes threshold $F_{\alpha}(p, n-p-1)$.Finally, it calculates $F$ 's observation value $F_{0}$.

If $F_{0} \leq F_{\alpha}(p, n-p-1)$, then it accepts $H_{0}$.The whole teaching structure does not pay attention to the ideological and political work's deep-going, and students even have negative resistance mood to ideological and political work. Private universities have a discount in employment, what is worse, 
students' learning enthusiasm is not high, and negative emotions are produced. Under the significance level $\alpha$,the paper thinks that linear relationship between $y$ and $x_{1}, x_{2}, \ldots, x_{\mathrm{p}}$ is not significant. The ideological and political education of the private universities are not carried out indepth, which will influence the healthy growth of the young students. That even will bring some hidden trouble for social stability.

When $F_{0} \geq F_{\alpha}(p, n-p-1)$, through the private universities' ideological and political work,it improves the private college students' scientific and cultural quality at the same time.It improves college students' ideological and political quality,and it guides students to set up the correct ideal faith.That can enhance students' political flair,then it effectively prevents and resists hostile forces' penetration.

In short, private universities run a school jointly between the individual enterprise group finance and public school. As a new education institution, it makes a positive contribution to the school system. Due to the uniqueness of private colleges, it makes the private universities' ideological and political work to lag behind. The ideological and political education often become a mere formality, and the thorough development is less. The sustainable development and educational unearthing are not deep-going in the ideological and political education's work .

\section{Conclusion}

This paper is on the basis of previous studies. The ideas of the mathematical model are applied to private universities' ideological and political work. It uses mathematical analysis to deepen education work in the actual education process. It explores optimized and effective private universities' ideological and political education. The paper pays attention to the college students' ability, and college students should learn how to judge. The paper pays attention to the ability to analyze the problems , the ability to solve problems. It strives to improve their own education consciousness. The ideological and political education mode's optimization will greatly improve the university students' learning consciousness and the ideological and political education's main body.It has great influence on its own development.

\section{Reference}

[1] Lizhongqing,Lichunxia.The research on private universities' ideological and political work. Journal of Ji'nan administrative college, 2012(04):78-83.

[2] Feihexiang, Liying, Zhouqian.Discussion on Ideological and political work mechanism innovation .The research on ideological education, 2009(11):24-26.

[3] SongBin, FengShujuan.Some thinkings on the private universities' ideological and political work. Zhejiang Shuren University Journal, 2009(03):11-14.

[4] Liuailing,Chenjing, Lumingyuan.Analysis of Ideological and political work's characteristics. China Adult Education, 2010(03):34-35.

[5] Siwei.The research on private universities' ideological and political education of " after 90 " college students. Hunan Normal University, 2009.

[6] Liuailing.Private universities ideological and political work characteristics and mechanism innovation . Hebei Normal University, 2009:445-447.

[7] Wangweidan, Sunjin.The research on independent college students' Ideological and political work . The school party's construction and ideological education,2007(6):78-82.

[8] Tanzhenya.Construction of learning style is the eternal theme of Ideological and political education. Chinese higher education, 2008( 20):56-59.

[9] Qinhe.Serving students' private universities' moral education's innovation mechanism.Chinese higher education, 2008 ( 21):103-106.

[10] Sunqiqi.Preliminary thinking on improving moral education in private universities. Science and technology information, 2006( 12):77-79.

[11] Jiahuaiqin. Data, model and decision . University of International Business and Economics press, 2004:277-285.

[12] Xuguoyan.Thinking on in-depth development of network ideological and political work. Chinese higher education, 2008 (20):56-59. 